\title{
Effects of 1-MCP and Pre-harvest Fruit Bagging Treatments on Cold Storability of the Red-fleshed Apple 'Kurenainoyume'
}

\author{
Kazuhiro Matsumoto ${ }^{1,2 *}$, Tomomichi Fujita² and Saki Sato $^{2}$ \\ ${ }^{1}$ Faculty of Agriculture, Shizuoka University, Shizuoka 422-8529, Japan \\ ${ }^{2}$ Fujisaki Farm, Faculty of Agriculture and Life Science, Hirosaki University, Fujisaki, Aomori 038-3802, Japan
}

The evaluation of storability for the type 2 red-fleshed apple 'Kurenainoyume' is essential to expand its consumption for table and processing use, as the cultivation area of this cultivar has extended year by year. There is also little available information whether cold storage affects the skin and flesh coloration of 'Kurenainoyume' (type 2 apples). In the present study, we evaluated the effect of 1-methylcyclopropene (1MCP) treatment on the storability of bagged and non-bagged fruit for respective table and processing use over 3 years. Furthermore, we determined the maximum storage duration of both bagged and non-bagged fruit with 1-MCP. No change was observed in the soluble solid content during cold storage regardless of 1-MCP and bagging treatments. The malic acid content, flesh firmness, and skin and flesh coloration decreased with longer storage duration, but the decrease in these parameters was alleviated by 1-MCP treatment. Without 1-MCP, the storage duration of both bagged and non-bagged fruit to maintain flesh firmness and coloration at acceptable levels was about 90 days after harvest (DAH). With 1-MCP, bagged fruit for table use could be stored for about 180-210 DAH with no severe decrease in flesh firmness. Non-bagged fruit for processing use could also be stored for the same duration as bagged fruit, but the flesh firmness severely deteriorated. Although cooling treatment during the fruit growing stage improved flesh coloration, we found that cold storage did not promote this factor.

Key Words: anthocyanin, cork spot like physiological disorder (CSPD), ethylene, Malus $\times$ domestica.

\section{Introduction}

'Kurenainoyume' is a red-fleshed type 2 apple cultivar registered in Japan in 2010 (Matsumoto et al., 2016). The harvest time of this cultivar is usually between late October and early November in northern prefectures such as Aomori Prefecture. Its typical deep red skin and pink flesh give it the attributes of a featured product in tourism farm shops. In addition, it is immediately shipped without storage to enjoy the differences in skin/flesh color in combination with other cultivars that differ in these attributes (Matsumoto, 2017). The pink flesh color is induced by the accumulation of anthocyanin, which also imparts a natural pink color to the juice. Moreover, the pink coloration is maintained

Received; August 27, 2017. Accepted; October 21, 2017.

First Published Online in J-STAGE on February 22, 2018.

This research was partially supported by JSPS KAKENHI Grant Numbers 24780020 and 16K18647.

* Corresponding author (E-mail: matsumoto.kazuhiro@shizuoka. ac.jp). after baking and the mild tarty taste of this cultivar is suitable for the production of sweets. The polyphenol content in the flesh of 'Kurenainoyume' is higher than that of conventional white-fleshed cultivars like 'Fuji', and the extract of 'Kurenainoyume' flesh is known to suppress the rise in blood sugar level (Maeda et al., 2016). Consequently, 'Kurenainoyume' is known as a natural product with beneficial health effects.

The high storability of 'Kurenainoyume' allows its consumption either directly or in the form of juice, jam, dry fruit, pies, and tarts during the apple off-season (Matsumoto, 2017). Stored 'Kurenainoyume' is given as a gift during special domestic events between December and April, such as Christmas, New Year, St. Valentine's Day, the doll festival in March, school graduation/entrance ceremonies during the end-March to early-April period, and cherry blossom viewing parties as well as in other events in Asian countries such as lunar New Year parties in February. The pink color of some processed products such as juice and jam is sensitive to light irradiation (Weber and Larsen, 2017) and easily disappears; this trait is disadvantageous for the 
production of high-quality processed goods. Therefore, we must construct a system to supply the stored fruit in-time in response to the processing demands and compensate for this disadvantage. However, we do not have enough knowledge related to the usage of stored 'Kurenainoyume' apples.

For table use (without processing) after cold storage, it is important to consider cork spot like physiological disorder (CSPD), a kind of sunburn on the skin of 'Kurenainoyume' apples (Matsumoto et al., 2018b). 'Kurenainoyume' fruits easily suffer from CSPD, and in severe cases, this disorder may reach the flesh part. To prevent CSPD, pre-harvest fruit bagging using lightimpermeable double-layered paper bags (2-layer bag) is necessary. Failing to do so may affect the commercialization of fruits (Matsumoto et al., 2018b). However, there are no reports on the development of CSPD during cold storage. On the other hand, pre-harvest fruit bagging treatment is labor-intensive and expensive work for growers. Hence, some growers aiming to use this cultivar to produce juice and jam have been attempting new cultivation systems without pre-harvest fruit bagging to reduce labor and cost. Therefore, it is desirable to provide information about the storability of 'Kurenainoyume' and changes in the parameters related to fruit quality such as skin/flesh coloration, flesh firmness, soluble solid content, and acidity during cold storage to all growers. In our previous reports, we showed an improvement in the flesh red coloration by low temperature treatment during the growing stage (Matsumoto et al., 2018a), which suggests the possibility of improvement in the flesh red coloration by cold storage after harvest. However, there are few available reports on the changes in the parameters related to fruit quality, including changes in the skin and flesh coloration in red-fleshed type 2 apples (Honda et al., 2014). In this study, we evaluated the changes in not only flesh firmness, but also the red coloration of the skin and flesh (fading or developing) and acid content using fruit with or without pre-harvest fruit bagging treatment. In addition, we also investigated the effects of 1methylcyclopropene (1-MCP) treatment on the parameters related to fruit quality during cold storage.

The results demonstrated that the skin/flesh coloration of 'Kurenainoyume' apple showed no improvement with cold storage after harvest. However, 1-MCP treatment was effective in retaining the flesh firmness and skin/flesh coloration for both bagging and nonbagging fruit. Based on the flesh firmness, we suggested that both bagged and non-bagged fruit treated with 1-MCP could be stored until 180-210 days after harvest (DAH), although the flesh firmness of nonbagged fruit was lower than that of bagged fruit. Results of our study could provide the growers with new insights to carry out cold storage of 'Kurenainoyume' apples depending on their purposes (table or processing use).

\section{Materials and Methods}

\section{Plant materials}

The experiments were conducted in an experimental farm of Hirosaki University, Fujisaki Farm $\left(40^{\circ} 39^{\prime} 25^{\prime \prime} \mathrm{N}, 140^{\circ} 29^{\prime} 9^{\prime \prime} \mathrm{E}\right)$, which is located in the northernmost tip area of the main island of Japan. The experiment was repeated three times between 2013 and 2015 seasons. The fruit was harvested from five 35year-old (10 years after top-grafting onto 'Jonathan') 'Kurenainoyume' apple trees (age in 2013) grafted onto Malus prunifolia trees, which were trained to a flat open center form $(5.0 \mathrm{~m} \times 3.5 \mathrm{~m}$ planting $)$. Pre-harvest fruit bagging treatment was conducted with the following procedures. About half of the fruit was randomly covered with light impermeable double-layered paper bags (2-layer bag, $194 \mathrm{~mm} \times 162 \mathrm{~mm}$; Masudaya Co., Aomori, Japan) on 39-54 days after full bloom (DAFB). All the paper bags of bagged fruit were removed on September 19, 2013 (118 DAFB), October 2, 2014 (144 DAFB), and September 25, 2015 (146 DAFB). The remaining half of the fruit was left uncovered by the paper bag (non-bagged fruit). The trees received an annual routine and were harvested on November 6, 2013 (166 DAFB), October 31, 2014 (173 DAFB), and October 28, 2015 (179 DAFB). The harvest timing of each year was decided by both flesh coloration and firmness. Among all the harvested bagged and non-bagged fruits, some severely injured fruits (CSPD and insect and bird attack) were removed. Each fruit was randomly divided into two treatment groups; half of these received 1-MCP treatment, while the other half were stored at room temperature $\left(15-20^{\circ} \mathrm{C}\right)$ until the storage treatment. The 1-MCP treatment was conducted as follows.

\section{Treatment with 1-MCP}

The fruit in wood boxes $(30 \times 62 \times 31 \mathrm{~cm})$ was put into a $3.5 \mathrm{~m}^{3}$ plastic tent and a $1000 \mu \mathrm{g} \cdot \mathrm{L}^{-1}$ of $1-\mathrm{MCP}$ atmosphere was applied for $24 \mathrm{~h}$ at room temperature $\left(15-20^{\circ} \mathrm{C}\right)$. The 1-MCP atmosphere was developed by dissolving $1.25 \mathrm{~g}$ of $0.63 \%$ 1-MCP tablet (AgroFresh Japan, Tokyo, Japan) in tap water and applying it continuously with a small fan in the plastic tent.

\section{Storage treatment}

In this experiment, we prepared four treatment groups: i) bagging control storage, ii) bagging + 1-MCP storage, iii) non-bagging control storage, and iv) nonbagging + 1-MCP storage. After 1-MCP applications, 10 samples of treated and non-treated fruit were separately and randomly put into polyethylene bags $(0.03 \times$ $400 \times 500$, Fukusuke Kogyo, Ehime, Japan) and all fruit in the polyethylene bag was stored in a refrigerator at $3^{\circ} \mathrm{C}$, relative humidity $70 \%$ until the fruit quality measurement. 


\section{Fruit quality measurement}

Fruit quality measurement was conducted on 0,30 , 90, and 150 DAH between the 2013 and 2015 seasons. Only in 2015, the measurements on 180, 210, and 240 DAH were conducted using 1-MCP-treated bagged and non-bagged fruit. On each measurement day, 1 polyethylene bag containing 10 fruit was randomly selected and 5 fruit were used for ethylene analysis $(n=5)$ and the other 5 fruit were used for fruit quality measurement $(\mathrm{n}=5)$.

Red coloration of the skin, outer flesh, and inner flesh were expressed as $a^{*}$ values of the Lab color space, as measurements were performed simultaneously on multiple samples. The $a^{*}$ values were measured at two points on the equatorial area using a color difference meter (NF333; Nippon Denshoku, Tokyo, Japan) and the average values were used as one data set. Higher $\mathrm{a}^{*}$ values indicated deeper red coloration of the sample (Dong et al., 1995). The fruit flesh was divided into two portions, inner or outer flesh, which were 2.0-3.5 or $0.1-1.5 \mathrm{~cm}$ from the skin surface, respectively. After the skin was removed, the flesh firmness was measured at two points on the equatorial area of the fruit using a penetrometer with an 11.1-mm tip (FT327; Facchini srl, Alfonsine, Italy). The total soluble solid content of the juice was determined using a digital refractometer (N-1; Atago, Tokyo, Japan). The total titratable acidity was measured by titration with $0.1 \mathrm{~N}$ sodium hydroxide $(\mathrm{NaOH})$ and expressed as malic acid equivalent. At each time point, we measured the internal ethylene content of the fruit.

The ethylene content was assessed using 5 randomly selected fruits. The upper-half cut of the fruit was immersed in $1 \%$ of hydrochloric acid in a desiccator attached to a vacuum pump and the internal air was collected by the water substitute method (Matsumoto et al., 2009). Ethylene was measured by injecting $1 \mathrm{~mL}$ of the collected gas into a gas chromatograph (G-3500;
Hitachi, Tokyo, Japan) equipped with a flame ionization detector and 60/80 mesh activated alumina column $(2.2 \mathrm{~mm}$ i.d. $\times 2.0 \mathrm{~m}, \mathrm{G}-3000$; GL Sciences, Tokyo, Japan). The column, detector, and injector temperatures were 70,140 , and $100^{\circ} \mathrm{C}$, respectively, and the flow rate of nitrogen as a carrier gas was $30 \mathrm{~mL} \cdot \mathrm{min}^{-1}$ (FrancoMora et al., 2005).

\section{Incidence of cork spot like physiological disorder (CSPD) (\%)}

'Kurenainoyume' is very susceptible to CSPD which is induced by long sunshine exposure from July to August (Matsumoto et al., 2018b). In the present study, fruit with more than 3 spots were defined as disordered fruit, and their frequency was calculated as the number of disordered fruit divided by the total number of fruit $(n=50)$, which were randomly selected from the fruit at harvest.

\section{Statistical analysis}

Data were analyzed using two-way analysis of variance (ANOVA) or Tukey-Kramer honestly significant difference (HSD) tests using JMP IN software (SAS Institute, Cary, NC, USA). Significant differences among the treatments were determined. A value of $P<$ 0.05 was considered statistically significant unless otherwise stated.

\section{Results}

Differences in fruit quality between bagged and nonbagged fruit at harvest

Analysis of variance demonstrated significant differences in malic acid contents, flesh firmness, internal ethylene contents, and skin color between bagged and non-bagged fruit at harvest. Of these differences, malic acid and internal ethylene contents were higher in the non-bagged fruit, while flesh firmness and a* values of skin were higher for the bagged fruit (Table 1). Regard-

Table 1. The differences in the fruit quality of 'Kurenainoyume' apples at harvest from 2013 to 2015.

\begin{tabular}{|c|c|c|c|c|c|c|c|c|c|c|}
\hline \multirow{2}{*}{ Bag } & \multirow{2}{*}{ Year } & \multirow{2}{*}{$\begin{array}{c}\text { Fresh } \\
\text { weight } \\
\text { (g) }\end{array}$} & \multirow{2}{*}{$\begin{array}{c}\text { Soluble } \\
\text { solid content } \\
\left({ }^{\circ} \text { Brix }\right)\end{array}$} & \multirow{2}{*}{$\begin{array}{c}\text { Malic acid } \\
(\mathrm{mg} / 100 \mathrm{~mL})\end{array}$} & \multirow{2}{*}{$\begin{array}{c}\text { Fresh } \\
\text { firmness } \\
(\mathrm{N})\end{array}$} & \multirow{2}{*}{$\begin{array}{l}\text { Internal } \\
\text { ethylene } \\
\text { content } \\
\text { (ppm) }\end{array}$} & \multicolumn{3}{|c|}{$a^{*}$ value } & \multirow{2}{*}{$\begin{array}{l}\text { Incidence of } \\
\text { cork spot like } \\
\text { physiological } \\
\text { disorder (\%) }\end{array}$} \\
\hline & & & & & & & Skin & Outer flesh & Inner flesh & \\
\hline \multirow{3}{*}{ Bagging } & 2013 & $329.3 b^{z}$ & $11.9 \mathrm{c}$ & $0.90 \mathrm{~d}$ & $65.8 \mathrm{bc}$ & $0.001 \mathrm{~d}$ & $43.2 \mathrm{a}$ & $22.6 \mathrm{a}$ & $14.3 \mathrm{a}$ & 0.0 \\
\hline & 2014 & $366.3 \mathrm{abc}$ & $12.6 \mathrm{ab}$ & $1.02 \mathrm{bc}$ & $73.3 \mathrm{a}$ & $0.280 \mathrm{~b}$ & $45.1 \mathrm{a}$ & $22.4 \mathrm{a}$ & $18.2 \mathrm{a}$ & 0.0 \\
\hline & 2015 & $387.8 \mathrm{ab}$ & $12.1 \mathrm{bc}$ & $1.03 \mathrm{abc}$ & $68.0 \mathrm{bc}$ & $0.104 \mathrm{c}$ & $40.9 \mathrm{a}$ & $19.8 \mathrm{a}$ & $14.5 \mathrm{a}$ & 0.0 \\
\hline \multirow{3}{*}{ Non-bagging } & 2013 & $325.0 \mathrm{c}$ & $12.8 \mathrm{ab}$ & $0.96 \mathrm{~cd}$ & $64.5 \mathrm{c}$ & $0.002 \mathrm{~d}$ & $30.9 \mathrm{~b}$ & $20.2 \mathrm{a}$ & $14.2 \mathrm{a}$ & 12.0 \\
\hline & 2014 & $405.6 \mathrm{a}$ & $12.8 \mathrm{a}$ & $1.10 \mathrm{ab}$ & $71.9 \mathrm{ab}$ & $0.356 \mathrm{a}$ & $34.9 \mathrm{~b}$ & $24.4 \mathrm{a}$ & $15.9 \mathrm{a}$ & 84.0 \\
\hline & 2015 & $373.4 \mathrm{abc}$ & $12.3 \mathrm{abc}$ & $1.12 \mathrm{a}$ & $65.9 \mathrm{c}$ & $0.122 \mathrm{c}$ & $33.4 \mathrm{~b}$ & $22.7 \mathrm{a}$ & $12.2 \mathrm{a}$ & 80.0 \\
\hline \multicolumn{11}{|l|}{ ANOVA $^{y}$} \\
\hline Bagging (A) & & ns & ns & $* *$ & $* *$ & * & $* *$ & ns & ns & - \\
\hline Year (B) & & ** & $*$ & ns & $* *$ & $* *$ & ns & ns & ns & - \\
\hline $\mathrm{A} \times \mathrm{B}$ & & ns & ns & ns & ns & ns & ns & ns & ns & - \\
\hline
\end{tabular}

z Different letters within the same column show a significant difference by Tukey-Kramer's HSD test at the $5 \%$ level $(\mathrm{n}=10)$.

${ }^{\mathrm{y}} \mathrm{ns}, *$, and $* *$ indicate non-significant and significant differences at the 5\% and 1\% levels, respectively, by two-way ANOVA. 
less of the treatment condition, some year to year variations in fresh weight, soluble solid contents, flesh firmness, and internal ethylene contents were observed. The fresh weight tended to be lower in 2013 than other years. In contrast, the soluble solid contents and flesh firmness were higher in 2014 as compared to other years. In addition, the value of internal ethylene contents was maximum in 2014 followed by 2015 and 2013. No differences were observed in the $a^{*}$ values of outer and inner flesh regardless of year or bagging treatment. In the present study, no CSPD symptoms were recorded in the bagged fruit, while severe CSPD incidence was recorded in the non-bagged fruit (Table 1). Year to year variations in the occurrence of CSPD in non-bagged fruit were observed; CSPD incidence was only $12.0 \%$ in 2013 , but it rose to more than $80.0 \%$ in 2014 and 2015.

\section{Effect of 1-MCP treatment on the storability of bagged fruit}

In 2013, ANOVA analysis indicated that storage of the bagged fruit resulted in a decrease in malic acid contents, flesh firmness, skin color, and flesh color (outer) with an extension in the storage duration with or without 1-MCP treatment, although Tukey-Kramer's HSD test indicated no differences in skin color or flesh color (outer) (Table 2). In contrast, the internal ethylene contents increased steadily with longer storage duration. Among the altered parameters, the reduction in flesh firmness and the fading of color (outer) slowed down after treatment with 1-MCP. Furthermore, 1-MCP inhibited the internal ethylene contents. No significant differences were observed in soluble solid contents or flesh color (inner).

In 2014, ANOVA analysis indicated that storage of bagged fruit resulted in a decrease in the malic acid contents, skin color, and flesh color (outer and inner) with longer storage duration with or without 1-MCP treatment (Table 2). Flesh firmness increased once at 30 DAH and then decreased only for the control group (without 1-MCP); thus, flesh firmness was retained by $1-\mathrm{MCP}$ treatment. The reduction in malic acid contents and skin color was also alleviated by $1-\mathrm{MCP}$ as compared with the control group, but the difference in malic acid contents could not be detected by Tukey-Kramer's HSD test. At harvest, internal ethylene contents showed high values and these values decreased at $30 \mathrm{DAH}$ and increased again at $90 \mathrm{DAH}$. Lowest values of internal ethylene contents were observed at $150 \mathrm{DAH}$ with or without 1-MCP treatment.

In 2015, ANOVA analysis indicated that malic acid contents, skin color, and flesh color (outer and inner) tended to decrease with an increase in the storage duration with or without 1-MCP treatment (Table 2). Fading of the outer flesh color was inhibited by 1-MCP, although Tukey-Kramer's HSD test indicated no differences between with or without 1-MCP treatment. The change in the flesh firmness observed was similar to that reported in 2014, and 1-MCP was useful to retain flesh firmness. Internal ethylene contents increased after storage and they were inhibited by 1-MCP.

The changes in fruit quality of 1-MCP treated bagged fruit from 180-240 DAH in 2015 are indicated in Table 3 . The bagged fruit had high flesh firmness (more than $60 \mathrm{~N}$ ) until $210 \mathrm{DAH}$ (Table 3), and the outer flesh color was 13.4, although the inner flesh color already indicated a very low value. Malic acid contents on both 210 and $240 \mathrm{DAH}$ were lower than that on $180 \mathrm{DAH}$. Soluble solid content and skin coloration did not change from 180 to 240 DAH (Table 3).

\section{Effect of 1-MCP treatment on the storability of non- bagged fruit}

In 2013, storage of non-bagged fruit resulted in a decrease in the malic acid contents, flesh firmness, and flesh color (outer and inner) with an extension in the storage duration with or without 1-MCP treatment (Table 4). In contrast, internal ethylene contents increased with the storage duration. Of the altered parameters, the reduction in malic acid contents, flesh firmness, and flesh color (outer and inner) were inhibited following 1-MCP treatment. The increase in the internal ethylene contents was also inhibited by 1-MCP.

In 2014, the storage of non-bagged fruit resulted in a decrease in the malic acid contents, flesh firmness, and flesh color (outer and inner) with storage duration despite 1-MCP treatment (Table 4). The loss in flesh firmness was improved by 1-MCP treatment; however, 1MCP treatment had no effect on the loss of malic acid contents and flesh color (outer and inner). In addition, the values of internal ethylene contents were high at harvest, decreased at $30 \mathrm{DAH}$, and increased again at $90 \mathrm{DAH}$; the lowest values of internal ethylene content were observed at $150 \mathrm{DAH}$. No differences were observed in the internal ethylene content among different treatment groups (with or without 1-MCP).

In 2015, malic acid contents, flesh firmness, and flesh color (outer and inner) tended to decrease with longer storage duration with or without 1-MCP treatment (Table 4). Loss of flesh color (outer and inner) was prevented to some extent by 1-MCP. The internal ethylene contents increased after storage, but reached the original levels after 1-MCP treatment.

The changes in fruit quality of 1-MCP treated nonbagged fruit during 180-240 DAH in 2015 are indicated in Table 5. The non-bagged fruit indicated low flesh firmness in this period. However, until $210 \mathrm{DAH}$, the firmness value remained around $50 \mathrm{~N}$ (Table 5). Skin coloration indicated some fluctuation, but soluble solid content, malic acid content, and flesh coloration (outer and inner) did not change in this period (Table 5). 
Table 2. Effects of 1-MCP treatment on changes in the quality of bagged 'Kurenainoyume' (for table use) during cold storage (2013-2015).

\begin{tabular}{|c|c|c|c|c|c|c|c|c|c|}
\hline \multirow{2}{*}{ Year } & \multirow{2}{*}{ Treatment } & \multirow{2}{*}{$\mathrm{DAH}^{\mathrm{z}}$} & \multirow{2}{*}{$\begin{array}{c}\text { Soluble } \\
\text { solid content } \\
\left({ }^{\circ} \text { Brix }\right)\end{array}$} & \multirow{2}{*}{$\begin{array}{c}\text { Malic acid } \\
(\mathrm{mg} / 100 \mathrm{~mL})\end{array}$} & \multirow{2}{*}{$\begin{array}{l}\text { Flesh } \\
\text { firmness } \\
(\mathrm{N})\end{array}$} & \multirow{2}{*}{$\begin{array}{c}\text { Internal } \\
\text { ethylene } \\
\text { content (ppm) }\end{array}$} & \multicolumn{3}{|c|}{$\mathrm{a} *$ value } \\
\hline & & & & & & & Skin & Outer flesh & Inner flesh \\
\hline \multirow{11}{*}{2013} & & 0 & $11.9 \mathrm{a}^{\mathrm{y}}$ & $0.90 \mathrm{a}$ & $65.8 \mathrm{ab}$ & $0.001 \mathrm{c}$ & $43.2 \mathrm{a}$ & $22.6 \mathrm{a}$ & $14.3 \mathrm{a}$ \\
\hline & & 30 & $11.4 \mathrm{a}$ & $0.94 \mathrm{a}$ & $77.6 \mathrm{a}$ & $0.031 \mathrm{c}$ & $41.4 \mathrm{a}$ & $14.2 \mathrm{a}$ & $10.4 \mathrm{a}$ \\
\hline & Cont. & 90 & $12.0 \mathrm{a}$ & $0.81 \mathrm{ab}$ & $69.2 \mathrm{ab}$ & $0.477 \mathrm{a}$ & $41.8 \mathrm{a}$ & $16.7 \mathrm{a}$ & $7.8 \mathrm{a}$ \\
\hline & & 150 & $11.5 \mathrm{a}$ & $0.67 \mathrm{c}$ & $57.8 \mathrm{~b}$ & $0.565 \mathrm{a}$ & $39.2 \mathrm{a}$ & $12.2 \mathrm{a}$ & $9.0 \mathrm{a}$ \\
\hline & & 30 & $11.6 \mathrm{a}$ & $0.94 \mathrm{a}$ & $81.0 \mathrm{a}$ & $0.002 \mathrm{c}$ & $40.8 \mathrm{a}$ & $21.2 \mathrm{a}$ & $14.4 \mathrm{a}$ \\
\hline & 1-МCP & 90 & $12.0 \mathrm{a}$ & $0.78 \mathrm{bc}$ & $73.2 \mathrm{ab}$ & $0.292 \mathrm{~b}$ & $39.7 \mathrm{a}$ & $20.6 \mathrm{a}$ & $13.6 \mathrm{a}$ \\
\hline & & 150 & $11.6 \mathrm{a}$ & $0.71 \mathrm{bc}$ & $77.9 \mathrm{a}$ & $0.301 \mathrm{~b}$ & $39.9 \mathrm{a}$ & $17.5 \mathrm{a}$ & $13.2 \mathrm{a}$ \\
\hline & ANOVA $^{\mathrm{x}}$ & & & & & & & & \\
\hline & DAH (A) & & ns & $* *$ & $* *$ & $* *$ & $*$ & $*$ & ns \\
\hline & 1-MCP (B) & & ns & ns & * & $* *$ & ns & $*$ & ns \\
\hline & $\mathrm{A} \times \mathrm{B}$ & & ns & ns & $\mathrm{ns}$ & $* *$ & $\mathrm{~ns}$ & ns & ns \\
\hline \multirow{11}{*}{2014} & & 0 & $12.6 \mathrm{a}$ & $1.02 \mathrm{a}$ & $73.3 \mathrm{~b}$ & $0.280 \mathrm{a}$ & $45.1 \mathrm{a}$ & $22.4 \mathrm{a}$ & $18.2 \mathrm{a}$ \\
\hline & & 30 & $13.0 \mathrm{a}$ & $0.94 \mathrm{ab}$ & $78.2 \mathrm{ab}$ & $0.013 \mathrm{c}$ & $41.0 \mathrm{ab}$ & $25.6 \mathrm{a}$ & $17.0 \mathrm{a}$ \\
\hline & Cont. & 90 & $12.6 \mathrm{a}$ & $0.80 \mathrm{bc}$ & $58.4 \mathrm{c}$ & $0.304 \mathrm{a}$ & $39.7 \mathrm{~b}$ & $15.0 \mathrm{c}$ & $11.5 \mathrm{ab}$ \\
\hline & & 150 & $12.8 \mathrm{a}$ & $0.51 \mathrm{~d}$ & $55.9 \mathrm{c}$ & $0.105 \mathrm{~b}$ & $34.4 \mathrm{c}$ & $13.4 \mathrm{c}$ & $7.5 \mathrm{~b}$ \\
\hline & & 30 & $12.7 \mathrm{a}$ & $0.91 \mathrm{ab}$ & $82.0 \mathrm{a}$ & $0.002 \mathrm{c}$ & $42.0 \mathrm{ab}$ & $22.1 \mathrm{ab}$ & $13.0 \mathrm{ab}$ \\
\hline & 1-MCP & 90 & $12.3 \mathrm{a}$ & $0.90 \mathrm{ab}$ & $70.7 \mathrm{~b}$ & $0.287 \mathrm{a}$ & $42.6 \mathrm{ab}$ & $15.4 \mathrm{bc}$ & $6.6 \mathrm{~b}$ \\
\hline & & 150 & $12.3 \mathrm{a}$ & $0.69 \mathrm{~cd}$ & $74.4 \mathrm{ab}$ & $0.085 \mathrm{~b}$ & $40.8 \mathrm{ab}$ & $13.4 \mathrm{c}$ & $6.5 \mathrm{~b}$ \\
\hline & ANOVA & & & & & & & & \\
\hline & DAH (A) & & ns & $* *$ & $* *$ & $* *$ & $* *$ & $* *$ & $* *$ \\
\hline & 1-MCP (B) & & * & * & $* *$ & ns & $*$ & ns & $\mathrm{ns}$ \\
\hline & $\mathrm{A} \times \mathrm{B}$ & & ns & ns & $* *$ & ns & $\mathrm{ns}$ & $\mathrm{ns}$ & $\mathrm{ns}$ \\
\hline \multirow{11}{*}{2015} & & 0 & $12.1 \mathrm{a}$ & $1.03 \mathrm{a}$ & $68.0 \mathrm{ab}$ & $0.104 \mathrm{e}$ & $40.9 \mathrm{a}$ & $19.8 \mathrm{a}$ & $14.5 \mathrm{a}$ \\
\hline & & 30 & $12.9 \mathrm{a}$ & $1.04 \mathrm{ab}$ & $71.9 \mathrm{ab}$ & $0.177 \mathrm{ab}$ & $38.5 \mathrm{ab}$ & $17.5 \mathrm{ab}$ & $13.8 \mathrm{a}$ \\
\hline & Cont. & 90 & $12.7 \mathrm{a}$ & $0.90 \mathrm{abc}$ & $65.0 \mathrm{~b}$ & $0.195 \mathrm{a}$ & $34.9 \mathrm{ab}$ & $14.8 \mathrm{ab}$ & $9.8 \mathrm{ab}$ \\
\hline & & 150 & $12.9 \mathrm{a}$ & $0.73 \mathrm{c}$ & $54.6 \mathrm{c}$ & $0.159 \mathrm{bc}$ & $35.3 \mathrm{ab}$ & $9.1 \mathrm{~b}$ & $3.7 \mathrm{~b}$ \\
\hline & & 30 & $12.9 \mathrm{a}$ & $1.03 \mathrm{ab}$ & $74.5 \mathrm{a}$ & $0.162 \mathrm{bc}$ & $39.4 \mathrm{ab}$ & $21.7 \mathrm{a}$ & $17.2 \mathrm{a}$ \\
\hline & 1-MCP & 90 & $13.1 \mathrm{a}$ & $0.87 \mathrm{bc}$ & $72.3 \mathrm{ab}$ & $0.119 \mathrm{de}$ & $34.4 \mathrm{~b}$ & $17.7 \mathrm{ab}$ & $10.9 \mathrm{ab}$ \\
\hline & & 150 & $12.7 \mathrm{a}$ & $0.81 \mathrm{c}$ & $65.3 \mathrm{~b}$ & $0.135 \mathrm{~cd}$ & $36.2 \mathrm{ab}$ & $15.8 \mathrm{ab}$ & $9.5 \mathrm{ab}$ \\
\hline & ANOVA & & & & & & & & \\
\hline & DAH (A) & & ns & $* *$ & $* *$ & $* *$ & * & $* *$ & $* *$ \\
\hline & 1-MCP (B) & & ns & ns & $* *$ & $* *$ & ns & $*$ & ns \\
\hline & $\mathrm{A} \times \mathrm{B}$ & & ns & ns & $*$ & $* *$ & ns & ns & ns \\
\hline
\end{tabular}

${ }^{z}$ DAH indicated the days after harvest.

y Different letters within the same column of each year show a significant difference by Tukey-Kramer's HSD test at the $5 \%$ level $(\mathrm{n}=5)$.

${ }^{x} \mathrm{~ns}, *$, and ** indicate non-significant and significant differences at the $5 \%$ and $1 \%$ levels, respectively, by two-way ANOVA.

Table 3. Effects of 1-MCP treatment on the long storability of bagged 'Kurenainoyume' apples (for table use) (2015).

\begin{tabular}{ccccccccc}
\hline \hline \multirow{2}{*}{$\mathrm{DAH}^{\mathrm{z}}$} & \multirow{2}{*}{$\begin{array}{c}\text { Soluble solid } \\
\text { content }\left({ }^{\circ} \text { Brix }\right)\end{array}$} & $\begin{array}{c}\text { Malic acid } \\
(\mathrm{mg} / 100 \mathrm{~mL})\end{array}$ & $\begin{array}{c}\text { Flesh firmness } \\
(\mathrm{N})\end{array}$ & $\begin{array}{c}\text { Internal ethylene } \\
\text { content }(\mathrm{ppm})\end{array}$ & \multicolumn{3}{c}{ Skin } & \multicolumn{2}{c}{ Outer flesh } & Inner flesh \\
\hline 180 & $12.9 \mathrm{a}^{\mathrm{y}}$ & $0.93 \mathrm{a}$ & $71.0 \mathrm{a}$ & $0.015 \mathrm{c}$ & $37.6 \mathrm{a}$ & $17.5 \mathrm{a}$ & $12.3 \mathrm{a}$ \\
210 & $12.0 \mathrm{a}$ & $0.69 \mathrm{~b}$ & $62.7 \mathrm{~b}$ & $0.104 \mathrm{~b}$ & $34.8 \mathrm{a}$ & $13.4 \mathrm{ab}$ & $4.0 \mathrm{~b}$ \\
240 & $11.9 \mathrm{a}$ & $0.63 \mathrm{~b}$ & $49.8 \mathrm{c}$ & $0.232 \mathrm{a}$ & $37.4 \mathrm{a}$ & $9.1 \mathrm{~b}$ & $5.8 \mathrm{~b}$ \\
\hline
\end{tabular}

${ }^{z}$ DAH indicated the days after harvest.

${ }^{y}$ Different letters within the same column show a significant difference by Tukey-Kramer's HSD test at the $5 \%$ level $(n=5)$. 
Table 4. Effects of 1-MCP treatment on changes in the quality of non-bagged 'Kurenainoyume' (for processing use) during cold storage (20132015).

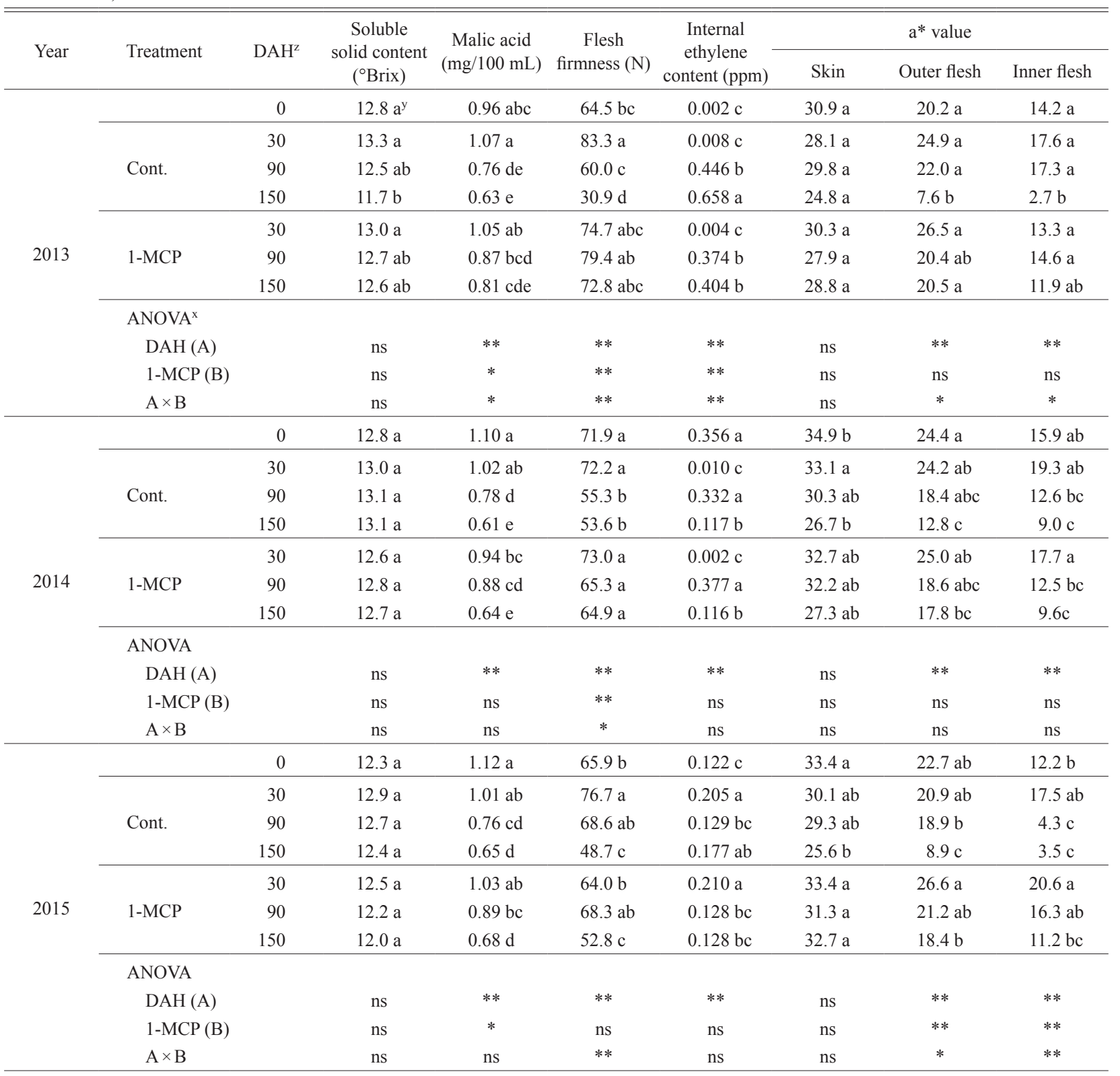

${ }^{z}$ DAH indicated the days afer harvest.

y Different letters within the same column of each year show a significant difference by Tukey-Kramer's HSD test at the 5\% level ( $\mathrm{n}=5)$.

${ }^{x} \mathrm{~ns}, *$, and $* *$ indicate non-significant and significant differences at the $5 \%$ and $1 \%$ levels, respectively, by two-way ANOVA.

Table 5. Effects of 1-MCP treatment on the long storability of non-bagged 'Kurenainoyume' apples (for processing use) (2015).

\begin{tabular}{|c|c|c|c|c|c|c|c|}
\hline \multirow{2}{*}{$\mathrm{DAH}^{\mathrm{z}}$} & \multirow{2}{*}{$\begin{array}{c}\text { Soluble solid } \\
\left.\text { content ( }{ }^{\circ} \text { Brix }\right)\end{array}$} & \multirow{2}{*}{$\begin{array}{c}\text { Malic acid } \\
(\mathrm{mg} / 100 \mathrm{~mL})\end{array}$} & \multirow{2}{*}{$\begin{array}{l}\text { Flesh firmness } \\
(\mathrm{N})\end{array}$} & \multirow{2}{*}{$\begin{array}{l}\text { Internal ethylene } \\
\text { content (ppm) }\end{array}$} & \multicolumn{3}{|c|}{$a *$ value } \\
\hline & & & & & Skin & Outer flesh & Inner flesh \\
\hline 180 & $11.1 \mathrm{a}^{\mathrm{y}}$ & $0.38 \mathrm{a}$ & $46.6 \mathrm{ab}$ & $0.012 \mathrm{~b}$ & $34.5 \mathrm{a}$ & $15.3 \mathrm{a}$ & $7.3 \mathrm{a}$ \\
\hline 210 & $12.0 \mathrm{a}$ & $0.51 \mathrm{a}$ & $51.3 \mathrm{a}$ & $0.099 \mathrm{~b}$ & $29.5 \mathrm{~b}$ & $14.1 \mathrm{a}$ & $7.8 \mathrm{a}$ \\
\hline 240 & $11.7 \mathrm{a}$ & $0.54 \mathrm{a}$ & $43.9 \mathrm{~b}$ & $0.313 \mathrm{a}$ & $30.9 \mathrm{ab}$ & $12.4 \mathrm{a}$ & $5.7 \mathrm{a}$ \\
\hline
\end{tabular}

z DAH indicated the days after harvest.

${ }^{y}$ Different letters within the same column show a significant difference by Tukey-Kramer's HSD test at the 5\% level $(n=5)$. 


\section{Discussion}

\section{Effect of cold storage on CSPD development}

Pre-harvest fruit bagging treatment is the most effective cultivation technique to prevent the development of CSPD in 'Kurenainoyume' apples. In a previous study, we revealed that the CSPD incidence largely depends on the sunshine duration (Matsumoto et al., 2018b). The duration of sunshine in 2014 and 2015 was longer than that of 2013 (349.7 and $347.2 \mathrm{~h}$ versus $277.9 \mathrm{~h}$, respectively, from July to August); therefore, the differences in sunshine duration affected the current results (Table 1). CSPD of 'Kurenainoyume' is a kind of sunburn, although the symptoms of CSPD are similar to that of cork spot and bitter pit (Matsumoto et al., 2018b). The bitter pit symptom of 'Honeycrisp' and 'Golden Delicious' apples was reported to develop during cold storage (Gago et al., 2016; Rosenberger et al., 2004). However, there is no information about the changes in CSPD symptoms during cold storage. In the present study, no CSPD symptoms developed during the storage period; the bagged fruit showed no new CSPD development and the non-bagged fruit did not show increased severity of CSPD during storage (Matsumoto et al., personal observation). These results indicate that it is not necessary for growers to consider the risk of CSPD development during cold storage.

\section{Effect of 1-MCP treatment on the storability of bagged fruit for table use}

Pre-harvest fruit bagging using a 2-layer bag is necessary for table use production of 'Kurenainoyume' fruit (Matsumoto et al., 2018b). The results of bagged fruit from 3 years' trials suggested that the changes in soluble solid contents were small, while those in malic acid contents, flesh firmness, skin color, and flesh color (outer and inner) tended to decrease regardless of 1MCP treatment (Table 2). However, the reduction, particularly in flesh firmness and flesh color (outer), could be alleviated by 1-MCP. Internal ethylene contents tended to increase during storage except in 2014, and they were inhibited by $1-\mathrm{MCP}$ to some extent. 1-MCP effectively represses the ethylene signal cascade by binding to the ethylene receptors and competing with ethylene (Dal Cin et al., 2006). Therefore, we expected a positive effect of 1-MCP treatment to inhibit the deterioration of fruit quality and internal ethylene contents. While 1-MCP treatment inhibited the deterioration of fruit quality, its effect on the inhibition of internal ethylene contents was mild. 'Kurenainoyume' possesses a homozygous $M d-A C S 1-2$ allele (Igarashi et al., 2011), which produces less ethylene and a firmer fruit than MdACS1-1/2 and MdACS1-1/1 genotypes (Oraguzie et al., 2007; Zhu and Barritt, 2008). This trait may have affected the results of the present study; 1-MCP treatment failed to show dramatic suppression of the internal ethylene production due to the genetic features.
It is difficult definitively decide the fruit quality suitable for table use, but we think that fruit showing around $60 \mathrm{~N}$ of flesh firmness with an approx. 15 of outer flesh $\mathrm{a}^{*}$ value are necessary to enjoy 'Kurenainoyume' fruit. When we applied these standards to decide the maximum storage duration for table use, fruit without 1-MCP were stored until $90 \mathrm{DAH}$ (Table 2). In contrast, 1-MCP-treated fruit dramatically extended their storability to 180-210 DAH while keeping their quality (Tables 2 and 3 ).

Effect of 1-MCP treatment on the storability of nonbagged fruit for processing use

Non-bagged fruit may be unsuitable for direct consumption due to CSPD incidence (Matsumoto et al., 2018b); however, it may be useful for the manufacturing of processed products. For processing, labor-saving fruit cultivation is an important point, which indicates the unsuitability of the pre-harvest fruit bagging treatment with a 2-layer bag for this purpose. In addition, once the stored fruit is processed, the product quality such as the juice color and jam change immediately due to the high sensitivity of anthocyanins to light irradiation (Weber and Larsen, 2017). We found that the color of 'Kurenainoyume' apple juice disappeared within 7 to 8 months (data not shown); therefore, the expiration date of the products was set within 6 months, although other qualities such as sugar and acid contents remained viable for more than 1 year. Hence, processed products of good quality may be produced when the stored fruit is used on time in response to the processing demands. Considering this, we carried out cold storage treatment with or without 1-MCP using non-bagged fruit.

The results of non-bagged fruit from 3 years (Table 4) demonstrated that malic acid contents, flesh firmness, and flesh color (outer and inner) tended to decrease, while the changes in soluble solid contents were small regardless of 1-MCP. The reduction in malic acid contents and flesh firmness was alleviated by $1-\mathrm{MCP}$ treatment in 2 of the 3 years. Although a clear improvement in flesh color (outer and inner) was observed after $1-\mathrm{MCP}$ treatment in only one year, 1-MCP tended to retain the levels of flesh color over the 3 years. However, no obvious reduction in skin color was observed after 1-MCP treatment, as non-bagged fruit showed less coloration at the start of the cold storage experiment.

It is worth mentioning that the reduction in flesh firmness was marked in 2013 (Table 4); however, this observation was not as promising as in the case of bagged fruit (Table 2). As the storability of bagged fruit is longer than that of non-bagged fruit (Kudo et al., 1991; Okamoto et al., 1982), pre-harvest fruit bagging techniques are commonly used for the long-term storage of apple fruit. However, Arakawa and Komori (2006) showed that there was no precise data related to the storability difference between bagged and nonbagged fruit, and that the longer storability of bagged 
fruit is related to the degree of maturation at harvest; in comparison with the non-bagged fruit, bagged fruit show delayed maturation, which needs further study. In contrast, it is known that the loss of fruit flesh firmness, including Japanese pears, is faster when the temperature during maturation is relatively low (Oya, 2006). However, the average temperature in the latter half of the developmental stage (late September to mid October) in 2013 was higher than that in 2014 and $2015\left(15.9^{\circ} \mathrm{C}\right.$ versus $14.5^{\circ} \mathrm{C}$ and $14.9^{\circ} \mathrm{C}$, respectively; Japan Meteorological Agency, Hirosaki Measurement Station: $\left.40^{\circ} 36^{\prime} 7^{\prime \prime N}, 140^{\circ} 27^{\prime} 3 " \mathrm{E}\right)$. Hence, unknown factor(s) other than temperature during the developmental stage may have been involved in the reduction of flesh firmness in 2013.

Generally, the acceptable levels for processing use are lower than those for table use. However, since flesh coloration is one of the important traits for processing use, we have to produce fruit with a 15 outer flesh a* value, a level comparable to that for table use. In addition, we must also pay attention to produce fruit with around $50 \mathrm{~N}$ of flesh even for processing use because not much juice can be extracted from fruit with low flesh firmness. When we considered these standards to decide the maximum storage duration for processing use, non-bagged fruit were stored until $90 \mathrm{DAH}$ without 1-MCP (Table 4). In contrast, the fruit treated with 1MCP showed longer storability (until 180-210 DAH) (Tables 4 and 5). Thus, the storage duration of nonbagged fruit for processing use can be improved from 90 to 210 DAH by 1-MCP treatment.

\section{Effect of cold storage on the skin and flesh coloration}

The skin and flesh color of 'Kurenainoyume' showed no improvement during cold storage (Tables 2-5). Thus, cool water treatment of the fruit during developmental stage was effective for flesh coloration (Matsumoto et al., 2018a); however, such effects were not recorded in the harvested fruit during cold storage. The skin color of the harvested apples such as 'Tsugaru' and 'Fuji' may be generally promoted by cold treatment (Bai et al., 2014; Ban et al., 2007; Ubi et al., 2006). Therefore, we expected a positive effect of cold storage at least on skin color. Dong et al. (1995) reported that the red color of green, pre-climacteric 'Royal Gala' apple skin increased after storage at $4^{\circ} \mathrm{C}$ in the dark. On the contrary, Ganai et al. (2015) reported that the a* value of well colored 'Red Delicious' apple skin decreased with an increase in the storage period at $4^{\circ} \mathrm{C}$ until $100 \mathrm{DAH}$. They also reported that the skin anthocyanin content slightly increased during the first 40 days of storage at $4{ }^{\circ} \mathrm{C}$, while the increased rate was higher in early harvested fruit as compared with late harvested fruit; however, the anthocyanin content decreased with an increase in the storage time from 40 to 100 DAH (Ganai et al., 2015). These results suggest the importance of the developmental stage of apple fruit used for cold storage; pre-climacteric and/or early harvested fruit may have a high potential for red coloration during cold storage, although our knowledge about flesh coloration during cold storage is limited. Honda et al. (2014) reported that 'Pink Pearl', a type 2 apple fruit, collected 1 month before harvest season, showed improvement in flesh coloration after 30-day storage at $4^{\circ} \mathrm{C}$ under dark conditions, while those collected at harvest season failed to show any such improvement in flesh coloration. However, no other study has reported the effects on flesh coloration of type 2 apples during cold storage. In the present study, we used well colored fruit (fully matured fruit). One of the reasons for the lack of any improvement in skin and flesh coloration of 'Kurenainoyume' may be the effect of the developmental stage of the fruit used. Further detailed studies are necessary to uncover the factors that affect skin and flesh coloration.

\section{Conclusion}

CSPD of 'Kurenainoyume' did not show any severe deteriorating traits during a cold storage period despite $1-\mathrm{MCP}$ and bagging treatments. Both bagged (table use) and non-bagged (processing use) fruit maintained an acceptable quality until $90 \mathrm{DAH}$ without 1-MCP treatment. 1-MCP treatment was effective for retaining the flesh firmness and skin/flesh coloration regardless of the bagging treatments; thus, 1-MCP treated fruit can be stored until 180-210 DAH for table or processing use. We demonstrated that the skin/flesh coloration of 'Kurenainoyume' apples decreased with the extension of the cold storage period after harvest. Therefore, growers should produce well colored fruit for long storage through suitable horticultural management.

\section{Literature Cited}

Arakawa, O. and S. Komori. 2006. Apple. p. 34-42. In: The Japanese Society for Horticultural Science (ed.). Horticulture in Japan 2006. Nakanishi Printing, Kyoto.

Bai, S., T. Saito, C. Honda, Y. Hatsuyama, A. Ito and T. Moriguchi. 2014. An apple B-box protein, MdCOL11, is involved in UV-B and temperature-induced anthocyanin biosynthesis. Planta 240: 1051-1062.

Ban, Y., C. Honda, Y. Hatsuyama, M. Igarashi, H. Bessho and T. Moriguchi. 2007. Isolation and functional analysis of a MYB transcription factor gene that is a key regulator for the development of red coloration in apple skin. Plant Cell Physiol. 48: 958-970.

Dal Cin, V., F. M. Rizzini, A. Botton and P. Tonutti. 2006. The ethylene biosynthetic and signal transduction pathways are differently affected by 1-MCP in apple and peach fruit. Postharvest Biol. Technol. 42: 125-133.

Dong, Y. H., D. Mitra, A. Kootstra, C. Lister and J. Lancaster. 1995. Postharvest stimulation of skin color in Royal Gala apple. J. Amer. Soc. Hort. Sci. 120: 95-100.

Franco-Mora, O., K. Tanabe, F. Tamura and A. Itai. 2005. Effects of putrescine on fruit set in 'Housui' Japanese pear (Pyrus pyrifolia Nakai). Sci. Hortic. 104: 265-273.

Gago, C. M. L., A. C. Guerreiro, G. Miguel, T. Panagopoulos, M. M. da Silva and M. D. C. Antunes. 2016. Effect of 
Calcium chloride and 1-MCP (Smartfresh ${ }^{\mathrm{TM}}$ ) postharvest treatment on 'Golden Delicious' apple cold storage physiological disorders. Sci. Hortic. 211: 440-448.

Ganai, S. A., H. Ahsan, I. A. Wani, A. A. Lone, S. A. Mir and S. M. Wani. 2015. Colour changes during storage of apple cv. Red delicious-influence of harvest dates, precooling, calcium chloride and waxing. Int. Food Res. J. 22: 196-201.

Honda, C., H. Iwanami, T. Hanada, Y. Moriya-Tanaka and M. Wada. 2014. Effect of light and temperature treatments on anthocyanin synthesis in 'Pink Pearl' apple. Hort. Res. (Japan) 13 (Suppl. 1): 262 (In Japanese).

Igarashi, M., Y. Hatsuyama, K. Matsumoto and Y. Shiozaki. 2011. Identification of parents of 'Kurenainoyume', a new cultivar of red-fleshed apple, by DNA markers. Bull. Fac. Agric. Life Sci. Hirosaki Univ. 13: 7-13 (In Japanese with English abstract).

Kudo, R., N. Obara and N. Kudo. 1991. 'Orin' apples in cold storage and the incidence of scald. Bull. Aomori Apple Exp. Stn. 27: 125-152 (In Japanese with English abstract).

Maeda, H., S. Yoshinaka, M. Fukuda, H. Ishikawa and K. Matsumoto. 2016. The healthy functionality and the attractiveness of a new red-fleshed apple 'Kurenainoyume'. New Food Industry 58 (9): 1-6 (In Japanese).

Matsumoto, K. 2017. Red-fleshed apple 'Kurenainoyume'. The cultivation and breeding studies at Hirosaki University, Fujisaki Farm. p. 211-231. In: V. Carpenter, X. Huang and K. Kanda (eds.). Apple industry under the globalization: World and Aomori (In Japanese). Hirosaki University Press, Hirosaki.

Matsumoto, K., J-P. Chun, Y. Takemura, N. Nakata and F. Tamura. 2009. Gum accumulation of Japanese apricot fruit (Prunus mume Sieb. et Zucc.) was expedited by jasmonate. J. Japan. Soc. Hort. Sci. 78: 273-278.

Matsumoto, K., T. Fujita, S. Sato and T. Moriguchi. 2018a. Effects of low temperature, shading, defoliation, and crop load on the flesh coloration of type 2 red-fleshed apple 'Kurenainoyume'. Hort. J. (In press).
Matsumoto, K., T. Kobayashi, T. Kougo, T. Fujita, S. Sato and T. Moriguchi. 2018b. Prevention of new cork spot-like physiological disorder in 'Kurenainoyume' apple by pre-harvest fruit bagging. Hort. J. doi: 10.2503/hortj.OKD-117. <https:// www. jstage.jst.go.jp/article/hortj/advpub/0/advpub_OKD-117/ pdf $>$.

Matsumoto, K., H. Maeda, T. Fujita, S. Sato and Y. Shiozaki. 2016. Apple breeding programs at Hirosaki University, Japan: yellow skin, red flesh, and large size. Acta Hortic. 1127: 29-34.

Okamoto, T., J. Harada, F. Nara, A. Osu and K. Kobayashi. 1982. Influence of "fruit bag" treatment on the tree upon the keeping quality of apples during storage. Bull. Fac. Agr. Hirosaki Univ. 38: 43-64 (In Japanese with English abstract).

Oraguzie, N. C., R. K. Volz, C. J. Whitworth, H. C. M. Bassett, A. J. Hall and S. E. Gardiner. 2007. Influence of Md-ACS1 allelotype and harvest season within an apple germplasm collection on fruit softening during cold air storage. Postharvest Biol. Technol. 44: 212-219.

Oya, Y. 2006. Prediction methods for harvesttime, fruit enlargement and fruit physiology disorder of Japanese pears based on weather habit reactions. Bull. Tochigi. Agr. Exp. Stn. 58: 17-29 (In Japanese with English abstract).

Rosenberger, D. A., J. R. Schupp, S. A. Hoying, L. Cheng and C. B. Watkins. 2004. Controlling bitter pit in 'Honeycrisp' apples. HortTechnology 14: 342-349.

Ubi, B. E., C. Honda, H. Bessho, S. Kondo, M. Wada, S. Kobayashi and T. Moriguchi. 2006. Expression analysis of anthocyanin biosynthetic genes in apple skin: effect of UV-B and temperature. Plant Sci. 170: 571-578.

Weber, F. and L. R. Larsen. 2017. Influence of fruit juice processing on anthocyanin stability. Food Res. Int. 100: 354-365.

Zhu, Y. and B. H. Barritt. 2008. Md-ACS1 and Md-ACO1 genotyping of apple (Malus $\times$ domestica Borkh.) breeding parents and suitability for marker-assisted selection. Tree Genet. Genomes 4: 555-562. 